\title{
RELATIONSHIP BETWEEN PHYSICAL ACTIVITY LEVELS AND SOCIOECONOMIC STATUS ON THE QUALITY OF LIFE OF MORBID OBESE CANDIDATES FOR BARIATRIC SURGE
}

Thaurus Vinícius de Oliveira Cavalcanti ${ }^{1 *}$, Bárbara Amaral Bruno Silva ${ }^{2}$, José Cristiano Faustino ${ }^{1}$, Luís Felipe Almeida Diniz', Paulo Roberto Cavalcanti Carvalho

${ }^{1}$ Departamento de Educação Física - Universidade Federal de Pernambuco; ${ }^{2}$ Laboratório Avançado de Educação Física e Saúde - Hospital das Clínicas de Pernambuco.

\section{ABSTRACT}

Objective: To investigate the relationship between perception of quality of life, levels of physical activity and socioeconomic status of morbidly obese candidates for bariatric surgery, registered in the outpatient clinic of HC/UFPE/EBSERH. Methods: Cross-sectional observational research conducted with sixty-two morbidly obese individuals candidates for bariatric surgery with age $=39,53 \pm 10,72$ years and $B M I=50,05 \pm 9,26 \mathrm{~kg} / \mathrm{m}^{2}$, where they were interviewed using the IPAQ, SF-36 and ABEP questionnaires. Spearman's correlation was used to correlate continuous variables and differences between groups were analyzed using the Kruskal-Wallis test. Results: The Physical Functioning domain had a significantly higher score $(p=0,01)$ for the level of Moderate physical activity $(61,05 \pm 25,03 ; n=19)$ compared to the Low level $(40,83 \pm 23,20 ; n=30)$; the Role-Physical domain had a significantly higher score $(p=0,029)$ for the level of High physical activity $(65,38 \pm 36,14 ; n=13)$ compared to those of Low level $(35,83 \pm 35,77 ; n=30)$. Individuals of socioeconomic status $B(n=17)$ had scores significantly higher than individuals of status $C(n=45)$ in the Physical Functioning $\left[X^{2}(1)=4,800 ; p<0.05\right]$, General Health $\left[X^{2}(1)=11.568 ; p<0.01\right]$, Vitality $\left[X^{2}(1)=7.278 ; p<0.01\right]$, Social Functioning $\left[X^{2}(1)=4.086 ; p<0.05\right]$, Role-Emotional $\left[X^{2}\right.$ $(1)=6.467 ; p<0.05]$ and Mental Health $\left[X^{2}(1)=7.055 ; p<0.01\right]$ domains. Conclusion: Morbidly obese candidates for bariatric surgery with low levels of physical activity have lower scores on physical components of quality of life and when framed in a lower socioeconomic status they report lower scores on physical and mental components of quality of life.

*Correspondence to Author:

Thaurus Vinícius de Oliveira Cavalcanti

Departamento de Educação Física - Universidade Federal de Pernambuco;

How to cite this article:

Thaurus Vinícius de Oliveira Cavalcanti, Bárbara Amaral Bruno Silva, José Cristiano Faustino, Luís Felipe Almeida Diniz, Paulo Roberto Cavalcanti Carvalho. RELATIONSHIP BETWEEN PHYSICAL ACTIVITY LEVELS AND SOCIOECONOMIC STATUS ON THE QUALITY OF LIFE OF MORBID OBESE CANDIDATES FOR BARIATRIC SURGE. International Journal of Aesthetic Medicine and Health, 2021, 4:8

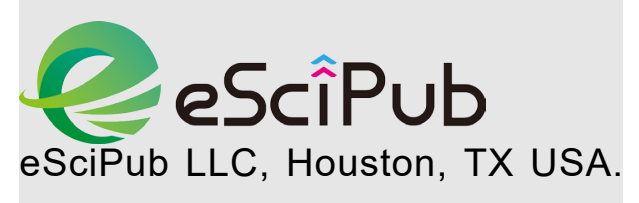

Website: http://escipub.com/ ical activity. socioeconomic status 